\title{
Ethnopharmacological evaluation of radal (leaves of Lomatia hirsuta) and isolation of 2-methoxyjuglone Henrik T Simonsen ${ }^{1}$, Anne Adsersen ${ }^{2}$, Louise Berthelsen², Søren B Christensen², Alfonso Guzmán² and Per Mølgaard*2
}

\author{
Address: ${ }^{1}$ Department of Plant Biology, Royal Veterinary and Agricultural University, Thorvaldsensvej 40, DK-1871 Frederiksberg C, Denmark and \\ 2Department of Medicinal Chemistry, Danish University of Pharmaceutical Sciences, Universitetsparken 2, DK-2100 Copenhagen, Denmark \\ Email: Henrik T Simonsen - hts@kvl.dk; Anne Adsersen - aad@dfuni.dk; Louise Berthelsen - louise.berthelsen@swedishorphan.com; \\ Søren B Christensen - sbc@dfuni.dk; Alfonso Guzmán - alfonso@quizak.dk; Per Mølgaard* - pm@dfuni.dk \\ * Corresponding author
}

Published: 3I August 2006

BMC Complementary and Alternative Medicine 2006, 6:29 doi:10.1186/1472-6882-6-29

This article is available from: http://www.biomedcentral.com/1472-6882/6/29

(C) 2006 Simonsen et al; licensee BioMed Central Ltd.

This is an Open Access article distributed under the terms of the Creative Commons Attribution License (http://creativecommons.org/licenses/by/2.0), which permits unrestricted use, distribution, and reproduction in any medium, provided the original work is properly cited.
Received: 24 May 2006

Accepted: 31 August 2006

\begin{abstract}
Background: Leaves of Lomatia hirsuta are used in traditional medicine in Chile under the common name of "radal". A tea of radal is traditionally used for treatment of cough, bronchial troubles, and asthma. In a preliminary screening, extracts of the leaves revealed antifungal activity, and the present phytochemical study was undertaken to explain this activity and support the traditional use.
\end{abstract}

Methods: Along with the traditional tea, extracts of the leaves were screened for antifungal and toxic activities. The profile of secondary constituents was obtained using GC-MS.

Results: 2-Methoxyjuglone was isolated from the leaves of Lomatia hirsuta and found to be active against the pathogenic fungus Candida albicans ( $M I C=8 \mu g / m L)$. Cinnamic acid and vanillic acid were identified as major constituents in the tea by GC-MS. The tea was found not to be toxic against Artemia salina.

Conclusion: The presence of phenolic acids with antimicrobial properties supports the traditional use of Radal, and encourages further studies.

\section{Background}

Lomatia hirsuta (Lam.) Diels ex Macbr. (Proteaceae) is a wild tree growing in Chile from Coquimbo to Chiloe (IV$\mathrm{X}$ Regions). It is distributed from the sea to sub mountain zones through 700-1200 m of altitude. Other Lomatia species in Chile are L. ferruginea (Cav.) R.Br. and L. dentata (R. et P.) R. Br. L. hirsuta is also present in Argentina, Ecuador and Peru [1]. Products prepared from the leaves of $L$. hirsuta are used in traditional medicine in Chile the product is under the common name of "radal". A tea of radal is used for treatment of cough, bronchial troubles, and asthma [2]. In a preliminary screening in our laboratory, methanol extracts of the leaves, but not of the stem, revealed antifungal activity, in particular against Candida albicans [3], and since our previous phytochemical study of the leaves did not explain the antifungal activity, the present study was undertaken. C. albicans and Aspergillus fumigatus were chosen as test organisms, since these organisms increasingly cause severe infections in patients with reduced immune response, e.g. HIV [4]. Penicillium expansum were also chosen as a test organisms, since this was a well establish culture in our lab. 
<smiles>COC1=CC(=O)c2c(O)cccc2C1=O</smiles>

1<smiles>[Mg]</smiles>

$2 \mathrm{R}=\mathrm{H}$ $3 \mathrm{R}=\mathrm{CH}_{2} \mathrm{CH}_{3}$<smiles>[R]OC(=O)c1ccc(O)c(OC)c1</smiles>

$5 \mathrm{R}=\mathrm{H}$

$4 \mathrm{R}=\mathrm{OH}$

$8 \mathrm{R}=\mathrm{CH}_{3}$

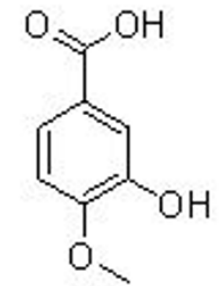

7

\section{Figure I}

Identified compounds from Lomatia hirsuta. 2-methoxyjuglone (I) cinnamic acid (2), ethyl cinnamate (3), 4-hydroxybenzoic acid (4), vanillic acid (5), methyl vanillate (6), isovanillic acid (7) and 4-hydroxyacetophenone (piceol) (8).
An earlier study of $L$. hirsuta confirmed the presence of the hydroxycoumarins umbelliferone and scopoletin and the flavonoids quercetin, rhamnetin, iso-rhamnetin, and quercetrine [5]. An infusion of the leaves of L. hirsuta was found to possess a mild anti-inflammatory effect [5].

Naphthoquinones, such as lomatiol, juglone and naphthazasin, are the major metabolites in some Lomatia species [6], including native plants such as L. ferruginea, and $L$. dentata, but have not previously been reported from $L$. hirsuta.

\section{Methods}

\section{Plant material}

The leaves of Lomatia hirsuta (Lam.) Diels ex J.F. Macbr. (Proteaceae) were collected next to the river Gol-Gol east of Osorno, Chile. The plants were identified in the field by Alfonso Guzman and their identity verified by Professor Jaime Zapata from Universidad de Los Lagos, Osorno, Chile. Voucher specimens have been placed at Universidad de Los Lagos and at the Danish University of Pharmaceutical Sciences.

\section{Extraction and isolation}

For the initial screening, $1 \mathrm{~g}$ of the dried leaf powder was ultrasonicated with $15 \mathrm{ml}$ of methanol for 30 minutes. The extract was concentrated after filtration to give an average yield of $20 \% \mathrm{w} / \mathrm{w}$. The active constituents were isolated from $320 \mathrm{~g}$ of dried leaves, which were extracted with first heptane and then methanol to give after vacuum evaporation of the solvent $1.5 \% \mathrm{w} / \mathrm{w}$ and $9.3 \% \mathrm{w} / \mathrm{w}$ of a residue, respectively. The residue of the methanol extract was partitioned between EtOAc and $\mathrm{H}_{2} \mathrm{O}$ and concentrated to yield residues of $7.3 \mathrm{~g}$ and $21.5 \mathrm{~g}$, respectively.

The EtOAc phase (7.3 g) was subjected to VLC (300 g silica gel, $10 \times 10 \mathrm{~cm}$ column) using $\mathrm{CH}_{2} \mathrm{Cl}_{2}(500 \mathrm{ml}), \mathrm{CH}_{2} \mathrm{Cl}_{2}$ EtOAc $19: 1$ to $1: 1$ (2500 and $1000 \mathrm{~mL}$ ), neat EtOAc (1000 $\mathrm{mL})$, and neat $\mathrm{MeOH}(1000 \mathrm{~mL})$ as eluents. Repeated LC (using $\mathrm{CH}_{2} \mathrm{Cl}_{2}$-EtOAc, EtOAc, MeOH as eluents) of the $\mathrm{CH}_{2} \mathrm{Cl}_{2}$ fraction yielded $8.4 \mathrm{mg}$ of 2-methoxyjuglone (1). The obtained ${ }^{1} \mathrm{H}$ and ${ }^{13} \mathrm{C}$ NMR spectra (Varian $300 \mathrm{MHz}$ at $25^{\circ} \mathrm{C}$, using TMS as standard) were similar to reported spectra of 2-methoxyjuglone [7].

The tea of the leaves was prepared by mixing $200 \mathrm{ml}$ of boiling water with $20 \mathrm{~g}$ of dried leaves and leaving the mixture for 30 minutes. The mixture was filtered and the filtrate concentrated by lyophilisation to give a yield of 9.4 $\mathrm{w} / \mathrm{w} \%$. For GC-MS study the tea was partitioned in an EtOAc fraction and a cold $\mathrm{H}_{2} \mathrm{O}$ fraction. Only the EtOAc fraction was analyzed in the GC-MS.

\section{Identification by GC-MS}

Compound 1-8 were identified in the biological active EtOAc fraction of the MeOH extract by GC-MS. The samples were dissolved in an appropriate solvent to c. $1 \mathrm{mg} /$ $\mathrm{mL}$. The GC (Agilent 6890N) inlet temperature was $200^{\circ} \mathrm{C}$. The oven temperature was held at $50^{\circ} \mathrm{C}$ for $2 \mathrm{~min}$ utes and then with a rate of $20^{\circ} \mathrm{C}$ per minute increased to $300^{\circ} \mathrm{C}$, which was held for 5 minutes. Total run time was 20 minutes with a constant flow of $1.2 \mathrm{ml} / \mathrm{min}$. The column was a capillary column (Agilent 19091S-433), length $30 \mathrm{~m}$, diameter $250 \mu \mathrm{m}$, film thickness $0.25 \mu \mathrm{m}$. The flow was split by 1:100 before introduction into the MS detector (Agilent 5973, electron impact (EI)): The EM voltage was $952.9 \mathrm{~V}$, with lower and upper Mass limits set to 30 and $1000 \mathrm{~m} / \mathrm{z}$. Quadrupole temperature was $150^{\circ} \mathrm{C}$ and source temperature was $230^{\circ} \mathrm{C}$.

The spectra were obtained by Enhancen ChemStation, MSD ChemStation D.01.02.16 provided by Agilent, compared with the spectra in the NIST/EPA/NIH Mass Spectral Library, Version 2.0 a ed. The library search was performed with the NIST Mass Spectral Search program against. All samples were analysed three times, and cinnamic and vanillic acids were run as standards to confirm the presence of these and similar compounds. 


\section{Antimicrobial screening}

A direct bioautographic method was used to determine the activity against Penicillium expansum (IMI 285521) and Aspergillus fumigatus (IBT 25732) [8]. A thin-layer chromatographic agar overlay technique [9] was used to determine the activity against Candida albicans (IMI 349010). These methods were used in the initial screening and the bio-guided fractionation. $100 \mu \mathrm{g}$ of each fraction and extract were tested and the activity was observed visually. Amphotericin B was used as positive control for C. albicans $(\mathrm{MIA}=1.2 \mu \mathrm{g})$ and nystatin for $P$. expansum (MIA = $0.5 \mu \mathrm{g})$.

A microplate method as previously described [10] was used with slight modifications to determine minimum inhibitory concentration values (MIC) of pure compounds against $C$. albicans. The compounds were dissolved in DMSO and diluted with Sabouraud broth (SAB) to a final DMSO concentration of $2 \%$. The plates were incubated for $48 \mathrm{~h}$ at $30^{\circ} \mathrm{C}$ and the growth of the fungi assessed after addition of MTT.

\section{Artemia salina toxicity assay}

The Artemia salina (brine shrimp) toxicity assay was performed as previously described [11]. Six concentrations were tested in 96-well microplates in six fold, each well containing 10-20 nauplii.

\section{Results and discussion}

A bioactivity guided fractionation lead to isolation of 8.5 mg of 2-methoxyjuglone (1) from a methanol extract of Lomatia hirsuta. In the antimicrobial assay with several organisms, the isolated 2-methoxyjuglone (1) was found to be active against Candida albicans with a MIC of $8 \mu \mathrm{g} /$ $\mathrm{mL}$, this is to the best of our knowledge the first report of antifungal activity of 2-methoxyjuglone. 1 was also detected in our GC-MS analysis of the EtOAc fraction of the methanol extract. Derivatives of juglone are commonly found in genus Lomatia, but this is the first report of juglone derivatives in L. hirsuta. Species belonging to the Proteaceae are generally known to contain phenolic and caffeic acid derivatives and cinnamic acid (2) can be used as a chemical marker for Proteaceae [12]. Thus the identification of $\mathbf{2 - 8}$ is not surprising when studying this family, but this is the first report of these compounds from this species.

Quinones (and among these naphthoquinones) are known for their antimicrobial but also toxic activity. In a recent report it was found that the activity could be referred to the orthoquinones (1,2 naphthoquinones) or paraquinones (1,4 naphthoquinones). The ortho was primarily antibacterial and the para mainly antifungal [13]. This is in good compliance with our observations where no antibacterial but antifungal activity was observed for 2methoxyjuglone, which is a paraquinone.

The GC-MS analysis of the EtOAc fraction of the methanol extract confirmed the presence of cinnamic acid (2), ethyl cinnamate (3), 4-hydroxybenzoic acid (4), vanillic acid (5), methyl vanillate (6), isovanillic acid (7) and 4hydroxyacetophenone (piceol) (8). Cinnamic acid was the major constituent in the crude methanol ethanol extract and the EtOAc fraction of this extract. None of the compounds 1-8 have hitherto been identified in L. hirsuta. The presence of previously identified scopoletin and umbelliferone as major constituents [5] was confirmed by the GC-MS analysis. These two constituents were found in various fractions of the EtOAc fraction of the methanol extract. Since no antimicrobial activity was observed in the heptane extract and the $\mathrm{H}_{2} \mathrm{O}$ fraction of the $\mathrm{MeOH}$ extract, these extracts were not analyzed on GC-MS.

The initial screening revealed antifungal activity of the methanol extract against $C$. albicans and against $P$. expansum, whereas no antibacterial activity was seen, this activity was found again in the EtOAc fraction of methanol extract in our bio-guided isolation of 1 . The identification of $\mathbf{1}-\mathbf{8}$ and the compounds reported in Erazo et al. [5], umbelliferone and scopoletin together with the flavonoids quercetin, rhamnetin, iso-rhamnetin, and quercetrine may explain the antifungal activity observed in the EtOAc fraction. In general phenolic acids (e.g. cinnamic acid), coumarins and flavonoids are known to have antimicrobial activities, all with different mechanism of actions and thereby different target organisms [14]. A literature study shows that 2 and 3 among several antimicrobial reports are reported to have broad antifungal activities [15] and that umbelliferone [16], scopoletin [17], 4, 5 and 7 [18-21] have all been shown to have antifungal and/or antibacterial properties. The occurrence of this range of compounds could be part of the explanation of the antimicrobial effects seen in the initial study [3] and in the later fractionation work. Erazo et al. [5] showed that their extract had mild anti-inflammatory effect. Piceol (8) is known to possess anti-inflammatory properties in mice [22].

The tea of the leaves from L. hirsuta is locally used for the treatment of cough, bronchial troubles and asthma. 2 and 4 were identified in the EtOAc fraction of the tea by GCMS, whereas none of the minor constituents was identified. 1 and 3 have previously been reported to be toxic $[23,24]$. But since high levels of juglones are previously reported only from the stem [13], the absence of 1 and 3 in the tea, makes it likely that the tea is non-toxic to humans. No toxicity of the tea against Artemia salina was demonstrated in a concentration range from 0.5 to $5 \mathrm{mg} /$ 
$\mathrm{ml}$, but it still remains to be established whether the tea could be toxic to human cells.

\section{Conclusion}

This is the first report of the presence of the compounds 1-8 in Lomatia hirsuta. Identification of 2-methoxyjuglone and the other compounds combined with the pharmacological test results encourage further studies on the effects of the tea of leaves of L. hirsuta. It also supports the traditional use of the plant.

\section{Competing interests}

To the best of our knowledge there is no competing interest involved with the publication.

\section{Authors' contributions}

HTS and LB performed the chemical laboratory work and the metabolite profiling. AA was involved in the screening of extracts for antifungal and toxic properties. SBC performed the structure elucidation of 1 . PM and AG performed the plant and data collection in Chile. All authors have read and approved the final manuscript.

\section{Acknowledgements}

We wish to thank Bente Gauguin and Katrine Krydsfeldt, Danish University of Pharmaceutical Sciences for valuable help with the screening of extracts and fractions, Jaime Zapata, Universidad de Los Lagos, Osorno, Chile for identification of the plant material, and Jens Christian Frisvad, Techinal University of Denmark for supplying the Aspergillus fumigatus. We are grateful to Beckett-Fonden (HTS) and Farmaceutforeningens Studiefond (LB) for financial support of the project.

\section{References}

I. Rodríguez R, Matthei O, Quezada M: Flora Arbórea de Chile Editorial de la Universidad de Concepción; 1982.

2. San Martin J: Medicinal plants in central Chile. Econ Bot 1983, 37:216-227.

3. Lauritsen J, Jorgensen L: Investigacion Etnofarmacologica de 21 Especies de Plantas Medicinales Nativas Usadas por los Mapuches del Sur de Chile Viking Books, Denmark; 200I.

4. Division of Bacterial and Mycotic Diseases [http:// www.cdc.gov/ncidod/dbmd/mdb/diseases.htm]

5. Erazo S, Garcia R, Backhouse N, Lemus II, Delporte C, Andrade C: Phytochemical and biological study of Radal Lomatia hirsuta (Proteaceae). J Ethnopharm 1997, 57:8I-83.

6. Moir M, Thompson H: Napthoquinones in Lomatia species. Phytochemistry 1973, I2: |35|-1353.

7. Moore RE, Scheuer PJ: Nuclear magnetic Resonance Spectra of Substituted Naphtoquinones. Influence of Substituents on the Tautomerism, Anisotropy, and Stereochemistry in the Napthazarin System. J Org Chem 1966, $31: 3272-3283$.

8. Homans AL, Fuchs A: Direct bioautography on thin-layer chromatograms as a method for detecting fungitoxic substances. J Chromatography 1970, 51:327-329.

9. Saxena G, Farmer S, Towers GHN, Hancock REW: Use of specific dyes in the detection of antimicrobial compounds from crude plant extracts using a thin layer chromatography agar overlay technique. Phytochem Anal 1995, 6:125-129.

10. Eloff JN: A sensitive and quick microplate method to determine the minimal inhibitory concentration of plant extracts for bacteria. Planta Med 1998, 64:7II-7I3.

11. Solis PN, Wright CW, Anderson MM, Gupta MP, Phillipson JD: A microwell cytotoxicity assay using Artemia salina (Brine shrimp). Planta Med 1993, 59:250-252.
12. Hegnauer R: Proteaceae. In Chemotaxonomie der Pflanzen, Band 9 Birkhäuser Verlag, Basel, Switzerland; 1990:294-3II.

13. Inouye S, Uchida K, Takizawa T, Yamaguchi H, Abe S: Evaluation of the effect of terpenoid quinones on Trichophyton mentagrophytes by solution and vapour contact. J Infect Chemother 2996, 12:100-104.

14. Cowan MM: Plant Products as Antimicrobial Agents. Clin Microbio Rev 1999, I 2:564-582.

15. Narasimhan B, Belsare D, Pharande D, Mourya V, Dhake A: Esters, amides and substituted derivatives of cinnamic acid: synthesis, antimicrobial activity and QSAR investigations. Euro J Med Chem 2004, 39:827-834.

16. Rodríguez-Gamboa T, Victor SR, Fernandes JB, Fo ER, Da Silva MFdGF, Vieira PC, Pagnocca FC, Bueno OC, Hebling MJA, Castro $\mathrm{CO}$ : Anthrone and oxanthrone $\mathrm{C}, \mathrm{O}$-diglycosides from Picramnia teapensis. Phytochemistry 2000, 55:837-844.

17. Carpinella MC, Ferrayoli CG, Palacios SM: Antifungal synergistic effect of scopoletin, a hydroxycoumarin isolated from Melia azedarach L. fruits. J Agric Food Chem 2005, 53:2922-2927.

18. Ma WG, Fukushi Y, Ducrey B, Hostettmann K, Tahara S: Phenolic glycosides from Eriosema tuberosum. Phytochemistry 1999, 5 I: 1087-I093.

19. Moura RMXD, Pereira PS, Januário AH, Franca SdC, Dias DA: Antimicrobial Screening and Quantitative Dentermination of Benzoic Acid Derivative of Gomphrena celosioides by TLC. Densitometry. Chem Pharm Bull 2004, 52:1342-1344.

20. Naz S, Ahmad S, Ajaz-Rasool S, Asad-Sayeed S, Siddiqi R: Antibacterial activity directed isolation of compounds from Onosma hispidum. Microbio Res 2006, 161:43-48.

21. Meng JC, Zhu QX, Tan RX: New antimicrobial mono- and sesquiterpenes from Soroseris hookeriana subsp. erysimoides. Planta Med 2000, 66:54|-544.

22. Alvarez MA, Rotelli AE, Pelzer LE, Saad JR, Giordano O: Phytochemical study and anti-inflammatory properties of Lampaya hieronymi Schum. Ex Moldenke. II Farmaco 2000, 55:502-505.

23. Kim S-H, Lee K-S, Son J-K, Je G-H, Lee J-S, Lee C-H, Cheong C-J: Cytotoxic Compounds from the Roots of Juglans mandshurica. I Nat Prod 1998, 61:643-645.

24. Perry NB, Foster LM, Lorimer SD, May BCH, Weavers RT, Toyota M, Nakaishi E, Asakawa Y: Isoprenyl Phenyl Ethers from Liwerworts of the Genus Trichocolea : Cytotoxic Acitivity, Structural Corrections, and Synthesis. J Nat Prod 1996, 59:729-733.

\section{Pre-publication history}

The pre-publication history for this paper can be accessed here:

http://www.biomedcentral.com/1472-6882/6/29/prepub

Publish with Bio Med Central and every scientist can read your work free of charge

"BioMed Central will be the most significant development for disseminating the results of biomedical research in our lifetime. "

Sir Paul Nurse, Cancer Research UK

Your research papers will be:

- available free of charge to the entire biomedical community

- peer reviewed and published immediately upon acceptance

- cited in PubMed and archived on PubMed Central

- yours - you keep the copyright

BioMedcentral 